\title{
Antimicrobial peptides, a promising alternative for the treatment of infectious diseases
}

\author{
Kevin Samael Olascoaga-Del Angel, Grecia Sánchez-Evangelista, Israel Carmona-Navarrete, \\ María del Carmen Galicia-Sánchez, Angélica Gómez-Luna, Susan Janneth Islas-Arrollo and \\ Jorge Ismael Castañeda-Sanchez \\ Universidad Autónoma Metropolitana Unidad Xochimilco, Ciudad de México, Mexico
}

\begin{abstract}
Microorganisms that cause diseases in humans are constantly evolving, which represents a challenge in the search for effective treatments against them. Even when currently there are several pharmacological alternatives available, sometimes they are inefficient for the control of infectious diseases, especially because pathogens have generated multiple resistance mechanisms against them. Antimicrobial peptides have been described in many species of organisms, from fungi, plants and insects to humans; currently, there are molecules that appear as a solution that can be effective in modern therapeutics. The advantage of these natural peptides lies in that they have been evolving almost the same amount of time than the species that produce them and their effect on the control of microorganisms is highly significant; some of these molecules are isolated from living organisms, others are starting to be produced by synthetic methods, which allows having access to an endless number of peptides with diverse therapeutic activities.
\end{abstract}

KEY WORDS: Antimicrobial peptides. Infectious diseases. Drug resistance.

\section{Human antimicrobial peptides}

Antimicrobial peptides (AMP) are relatively small molecules that contain between 12 and 60 amino acids, which are part of the defense response of various species of organisms and participate by mediating the primary response to several pathogens such as bacteria, parasites, and to viral and fungal infections. In mammals, they are synthesized in the skin, mucous membranes or sites prone to infections. ${ }^{1}$

The first AMP of animal origin was isolated from rabbit leukocytes in $1956 .{ }^{2}$ Currently, more than 5000 AMPs of natural origin, both from eukaryotic (animals, plants, fungi, insects) and prokaryote cells (bacteria), have been discovered or synthesized. ${ }^{3,4}$

AMPs in humans are capable of activating different immune response mechanisms such as phagocytosis, releasing prostaglandins, neutralizing lipopolysaccharide effects, increasing the number of immune cells at inflammation sites and repairing wounds by activating healing systems. ${ }^{5}$ These molecules usually have positive charge and are classified in two large groups: defensins and cathelicidins. ${ }^{6}$

According to their molecular structure, defensins are subdivided into $\alpha$ and $\beta .^{7}$ They are produced by most somatic cells and by immune response cells; they occur at high concentrations at the site of inflammation, in infectious processes, and some are detected in plasma at basal concentrations. ${ }^{8}$

$\alpha$ defensins contain 6 cysteine residues and 3 disulfide bridges, and are produced by leukocytes and epithelial cells. There are $6 \alpha$ defensins described in humans; the first 4 were identified in neutrophils (HNP 1-4) and the other two in Paneth intestinal cells. ${ }^{9}$

$\beta$-defensins have structures similar to those of the $\alpha$ type. There are four types of human $\beta$ defensins (hBD 1-4); they are produced by epithelial cells, cells of the respiratory and urinary tract, as well as by keratinocytes. ${ }^{8}$
Gac Med Mex. 2018;154:582-588

Contents available at PubMed www.gacetamedicademexico.com 
Cathelicidins are short peptides that contain an amino-terminal group and at the other end a carboxyl-terminal group; the charge of this molecule is positive, and it is therefore considered a cationic peptide. Cathelicidins show rapid action against pathogens, are potent and contain a broad spectrum of antimicrobial activity. The cathelicidin with the highest relevance described in humans is LL-37, made up by a helical $\alpha$ structure; the cells that produce it secrete it in its inactive form and its activation is carried out by proteases, leaving a peptide of 37 amino acid residues with two leucines next to each other in one extreme. ${ }^{7}$

\section{General mechanism of action}

The general mechanism by means of which peptides exert their action consists in damaging the pathogen cell membrane. AMPs interaction of with the microorganism is by means electrostatic forces between their amino-positive residue and the negative charge of the pathogen cell membrane. AMPs interaction with the pathogenic cell depends on the pathogen membrane composition, as well as on the concentration of the available antimicrobial peptide. If there is AMP affinity for the pathogen membrane, intramembrane pores will be formed through the bilayer lipid membrane, which causes its lysis and, therefore, its death..$^{10}$

Almost all AMPs interact with lipids of the cell membrane, but other require receptors to exert their activity. ${ }^{11}$ Possibly, cell death caused by AMPs involves membrane synthesis interruption followed by cell lysis. Not always does the mechanism focus on the pathogen membrane; interactions of AMPs with other targets have been described, including the cell wall, DNA, RNA and molecules involved with the synthesis of proteins. ${ }^{12}$

AMPs potential and applications are almost unlimited, since thousands of these molecules been characterized in nature and, in addition, millions of possible peptides with pharmacological activity can be synthetically obtained. According to the results of clinical studies, in animal models and in vitro studies, it has been suggested that AMPs may be highly promising molecules for the treatment of infectious diseases. ${ }^{13}$ Even when human AMPs are effective, most research has focused on obtaining and purifying of molecules from insects, plants and other mammals.

\section{AMPs in the treatment of infectious diseases}

AMPs are being used in the treatment of diseases caused by pathogens, with some being at experimental phases and other already being marketed; for example, AMPs are used against fungal agents such as Candida albicans, Cryptococcus neoformans and Fusarium oxysporum; ${ }^{14}$ some topically-applied antiviral peptides that fight infection with human immunodeficiency virus and human papilloma virus have been developed, ${ }^{15}$ as well as AMPs that fight protozoa and nematodes ${ }^{16}$ and against gram-negative bacteria; ${ }^{17}$ some others are used for their neuroprotective and anti-tumor effect. 18,19

\section{Antifungal AMPs}

Fungi are an extensive group of microorganisms that are present in almost any environment; they are part of the human and animal microbiota, and some have the ability to cause dangerous diseases for humans, most of them non-lethal but chronic. ${ }^{20}$

Antifungal AMPs properties have been under investigation for more than 40 years. Recently, interest in antifungal compounds has grown owing to the resistance mechanisms developed by pathogens of this type. ${ }^{21}$ Approximately 100 peptides with antifungal properties have been isolated and are at different stages of research. Most are of natural origin, although the number of semi-synthetic and synthetic peptides is increasing. Antifungal AMPs are usually linear and cyclical molecules, with amphipathic or hydrophobic properties, exhibit lysis, binding and external membrane rupture activity. ${ }^{22}$

Antifungal AMPs mechanism of action is poorly known. Some peptides bind to nuclear envelope proteins of certain species of fungi, producing reactive oxygen species, ion output flow and ATP; this series of events results in cell death. Some AMPs contain mitochondrial regulatory proteins that are involved in fungal energy metabolism, which positively regulates their synthesis and decreases mitochondrial ATP synthesis. ${ }^{23}$ Another mechanism is membrane surface tension alteration, which elicits the formation of pores and the release of $\mathrm{K}^{+}$and other vital ions. ${ }^{24,25}$

The anti-fungal AMPs with greater importance and that, in addition, are structurally related are defensins isolated from plants, animals and insects. ${ }^{26}$ 
Table 1. Antifungal peptides

\begin{tabular}{|c|c|c|c|c|c|}
\hline Compound & Company & Structure & Origin & Use & Evaluation phase \\
\hline $\begin{array}{l}\text { Iseganan. }^{28} \\
(\text { IB-367) }\end{array}$ & $\begin{array}{l}\text { Intrabiotics } \\
\text { Pharmaceuticals }\end{array}$ & $\begin{array}{l}\text { Peptides with disulfide } \\
\text { bridges }\end{array}$ & Pig leukocytes & $\begin{array}{l}\text { Anticancer } \\
\text { therapy-induced } \\
\text { mucositis }\end{array}$ & Phase III \\
\hline $\begin{array}{l}\text { Omiganan. }{ }^{28} \\
\text { (MBI-226) }\end{array}$ & Microbiologix Biotech & Cationic peptide & Bovine neutrophils & $\begin{array}{l}\text { Catheter infection } \\
\text { reduction }\end{array}$ & Phase III \\
\hline Cm-p1. ${ }^{29}$ & Havana University & Hydrophobic $\alpha$-helix & $\begin{array}{l}\text { Cenchrtitis } \\
\text { muricatus }\end{array}$ & $\begin{array}{l}\text { Inhibitor of several } \\
\text { filamentous fungi in vitro } \\
\text { activity }\end{array}$ & Phase I \\
\hline Arenicine- $1 .{ }^{30}$ & Adenium Biotech & $\beta$-helix & Arenicola marina & Against Candida spp. & Preclinical \\
\hline ApoEdpL-W. ${ }^{31}$ & & Lipoprotein & Synthetic & Against Candida spp. & Phase II \\
\hline HM-1 killer ${ }^{32}$ & $\begin{array}{l}\text { Nigata University \& Applied } \\
\text { Life Sciences }\end{array}$ & Toxin & $\begin{array}{l}\text { Williopsis mrakii } \\
\text { toxin }\end{array}$ & $\begin{array}{l}\text { Against Candida spp. and } \\
\text { Cryptococcus spp. }\end{array}$ & Phase I \\
\hline PAF-26 $6^{33}$ & $\begin{array}{l}\text { Instituto de Agroquímica y } \\
\text { Tecnología de Alimentos-CSIC }\end{array}$ & Hexapeptide & Synthetic & $\begin{array}{l}\text { Neurospora crassa } \\
\text { Penicillium digitatum } \\
\text { Saccharomyces } \\
\text { cerevisiae }\end{array}$ & Phase I \\
\hline Echinocandin $\mathrm{B}^{34}$ & Pharmatech & Lipopeptide & $\begin{array}{l}\text { Zalerion arboicola } \\
\text { fermentation }\end{array}$ & $\begin{array}{l}\text { Pneumocystis carinii } \\
\text { Aspergillus aculeatus }\end{array}$ & Phase II \\
\hline Pneumocandin ${ }^{35}$ & Pharmatech & Ether phosphate & Semisynthetic & Candida albicans & Clinical \\
\hline Mulundocandin ${ }^{35}$ & Aventis Pharma Deutschland & Lipopeptide & $\begin{array}{l}\text { Aspergillus } \\
\text { syndowi }\end{array}$ & $\begin{array}{l}\text { Candida albicans } \\
\text { Aspergillus niger }\end{array}$ & Phase II \\
\hline
\end{tabular}

The commercialization of peptides with antifungal activity is relatively recent. The United States Food and Drug Administration has approved antifungal peptides that have been shown to be viable in the treatment of common pathogens in humans; many of these molecules are marketed in the form of topical application $^{27-35}$ (Table 1).

\section{Antiviral AMPs}

Some diseases in humans and animals are caused by viruses such as influenza, dengue, hepatitis C, herpes simplex, just to name a few. Against them, antiviral therapies are limited, even for some a cure has not yet been found; in addition, the formation of resistance of these viruses to drugs has been increased, and antiviral therapy is therefore currently a challenge. The innovations to meet this challenge include antiviral peptides (AVPs), which promise to be excellent options. ${ }^{36}$

AVPs are a part of antimicrobial peptides that can act directly or through the immune response by inhibiting one or more stages of the viruses' life cycle, either at entry, replication, transcription, etc., showing a clear antiviral effect. ${ }^{37}$
In 1985, one of the first studies of these AVPs was revealed, where herpes simplex virus replication inhibition was demonstrated. ${ }^{37}$ Subsequently, other researchers took this as a basis to continue working with antiviral development.

Some advantages of AVP-based drugs in relation to the conventional ones include their low molecular weight, higher efficiency, lower toxicity and fewer side effects. These AVPs can be easily modified with the addition of chemical groups or amino acids to improve their activity and stability. The first AVP that approved the clinical trials was enfuvirtide (T20), an HIV fusion inhibitor that is currently marketed under the name Fuzeon. 38,39

\section{Cecropin and melittin}

Cecropin and melittin are $\alpha$-helix antimicrobial peptides isolated from insects with antiviral and antimicrobial (gram-negative) activity. The cecropin family includes sarcotoxins, hyphancin, enboncin and spodopsin.

Melittin is a cationic peptide of two $\alpha$-helices bound by a flexible segment and amphipathic structure; it has 26 amino acid residues and its action consists in 
inhibiting murine retroviruses, tobacco mosaic viruses and herpes simplex virus replication, as well as promoting viral membranes direct lysis. At low concentrations, it also shows antiviral activity for chronically HIV-1-infected T cells. ${ }^{40,41}$

\section{Alloferons}

Alloferons are peptides isolated from Calliphora vicina fly larvae hemolymph, which are produced as 13-residue (alloferon 1) and 12-residue molecules (alloferon 2); the name was given to demonstrate functional similarity to the cytokine known as interferon. Their activity was demonstrated with a synthetic peptide in a model of mice with lethal pulmonary infection with human influenza virus $A$ and $B$. When alloferon was administered, mortality was prevented in most animals infected with type A influenza virus, in addition to stimulating resistance to influenza $B$ virus infection. The results were almost equivalent to those observed with the administration of ribavirin, and alloferon was thus shown to have antiviral activity. ${ }^{42}$

\section{N-myristoylated peptide}

It is an antiviral compound with low molecular weight of $916 \mathrm{kDa}$ extracted from the tobacco caterpillar larvae Heliothis viresces hemolymph that has six amino acids; the $\mathrm{N}$-terminus portion of this peptide contains the fatty acid myristoyl, while the C-terminus, histidine with two methyl groups, which confers permanent positive charge. The antiviral action of this compound corresponds to the inhibition of the binding of viruses to the host membrane cytoplasmic side, which prevents the assembly of viral particles. Thanks to its low molecular weight and non-polar nature, it can improve its ability to cross the plasma membrane, where it can inactivate viruses such as HIV-1 and HSV $-1 .{ }^{42}$

\section{AVPs mechanisms of action}

Peptides such as alloferon stimulate natural killer (NK) cells and the production of type 1 interferons, which collaborate together by activating NK cells cytotoxicity, which actively participate in the control viral infections. ${ }^{43}$

Another mechanism of action of peptides is the influence on the intracellular steps of viral infection, interaction with DNA and viral messenger RNA. Examples of this are melittin and cecropin $A$, which inhibit the production of HIV-1-associated cells by gene expression suppression. Cecropin A also inhibits the multiplication of Sendai virus by reducing the synthesis of viral proteins without affecting the host cell protein synthesis. ${ }^{40}$

Being a membrane protein, melittin is able to interfere with cell signal transduction pathways such as phospholipase A2 activation, and decrease carmodulin and protein $C$ kinase activities; this is how it can change the balance and stimulating or inhibitory transcription activity in HIV-1-infected cells. It can also be involved in post-transcriptional regulation of human immunodeficiency virus gene expression and influence on the regulation of large and intermediate messenger RNAs; preliminary studies reveal that it also inhibits the replication of retroviruses such as that which causes murine leukemia, as well as the feline immunodeficiency virus. ${ }^{42}$

Another AVP example is the $\mathrm{N}$-myristoylated peptide, which acts on HIV viral control; its probable mechanism is the inhibition of assembly or budding of the virus in host cells. ${ }^{44}$

Cell-penetrating peptides are molecules that increase cell uptake and traffic towards the cytoplasm of peptides that might have antiviral effects; basically, they insert into membranes, allowing the passage of really effector molecules. ${ }^{45,46}$

\section{Antibacterial AMPs}

Antibacterial AMPs have started being used as an alternative to the use of antibiotics, which currently are not enough and some are no longer efficient in bacterial control. Most bacterial pathogens have resistance mechanisms to current drugs, which allows them to survive and even spread in their hosts. The use of AMPs could be a good alternative, especially those that are of synthetic origin and that are already in clinical phases of research ${ }^{47-50}$ (Table 2) or those that are directly isolated from organisms; most are still on laboratory experimentation phase $\mathrm{e}^{51-54}$ (Table 3).

Multiple mechanisms are used by AMPs for the control of bacteria, depending on each species; generally, they act on membrane permeabilization, metabolism disruption and DNA and protein function interruption. ${ }^{55}$ 
Gaceta Médica de México. 2018;154

Table 2. Peptides with antibacterial effect

\begin{tabular}{|c|c|c|c|c|c|}
\hline Compound & Company & Structure & Origin & Inhibited microorganism & Evaluation phase \\
\hline $\mathrm{BmKn} 2^{48}$ & Thammasat University & $\begin{array}{l}\text { Alpha-helical, basic peptide } \\
\text { without disulfide bridge }\end{array}$ & Scorpion & Miseria gonorrheae & Phase II \\
\hline GL $13 K^{49}$ & University of Minnesota & $\begin{array}{l}\text { 13-amino acid antimicrobial } \\
\text { peptide }\end{array}$ & $\begin{array}{l}\text { Human salivary } \\
\text { glands }\end{array}$ & $\begin{array}{l}\text { Pseudomonas aeruginosa } \\
\text { biofilms reduction }\end{array}$ & Clinical \\
\hline Alysterin-150 & Bio-X & $\beta$-helix & Synthetic & Escherichia coli & Clinical \\
\hline A3APO 50 & University of Minnesota & Lipopeptide & Synthetic & $\begin{array}{l}\text { Escherichia coli } \\
\text { Salmonella spp. }\end{array}$ & Preclinical \\
\hline XMP. $629^{13}$ & Xoma technology & 9-amino acid peptide & Synthetic & Propionibacterium acnes & Phase I \\
\hline CEME $^{51}$ & $\begin{array}{l}\text { British Columbia } \\
\text { University }\end{array}$ & $\alpha$-helix & Synthetic & $\begin{array}{l}\text { Staphylococcus aureus } \\
\text { Staphylococcus epidermidis } \\
\text { Staphylococcus pneumoniae }\end{array}$ & Clinical \\
\hline CEMA $^{51}$ & $\begin{array}{l}\text { University of British } \\
\text { Columbia }\end{array}$ & $\begin{array}{l}\text { Modified CEME with } 2 \text { extra } \\
\text { peptides }\end{array}$ & $\begin{array}{l}\text { Produced by } \\
\text { transgenic plants }\end{array}$ & $\begin{array}{l}\text { Porphyromonas gingivalis } \\
\text { Streptococcus mutans }\end{array}$ & Clinical \\
\hline MBI 594AN ${ }^{13}$ & Microbiologix Biotech & Lipopeptide & Synthetic & Propionibacterium acnes & Phase II \\
\hline Neuprex ${ }^{13}$ & Xoma technology & $\beta$-helix & Synthetic & Neisseria meningitidis & Phase II \\
\hline
\end{tabular}

Table 3. Human-isolated peptides with antibacterial effect

\begin{tabular}{|c|c|c|c|c|}
\hline Antimicrobial peptide & Structure & Production/synthesis & Action & Inhibited microorganisms \\
\hline hBD3 defensins ${ }^{52,53}$ & $\begin{array}{l}\text { Linear peptides with alpha helical } \\
\text { structure }\end{array}$ & Inflammatory stimuli & Innate response activation & $\begin{array}{l}\text { Staphylococcus aureus } \\
\text { Mycobacterium tuberculosis }\end{array}$ \\
\hline Lactoferrins ${ }^{54,55}$ & $\begin{array}{l}\text { Single polypeptide chain, folded } \\
\text { in two symmetric globular lobes }\end{array}$ & $\begin{array}{l}\text { Produced by mucosal } \\
\text { epithelial cells }\end{array}$ & $\begin{array}{l}\text { Bacteriostatic and } \\
\text { bactericidal functions }\end{array}$ & $\begin{array}{l}\text { Listeria monocytogenes } \\
\text { Streptococcus mutans } \\
\text { Staphylococcus aureus } \\
\text { Bacillus stearothermophilus }\end{array}$ \\
\hline
\end{tabular}

\section{Antiparasitic AMPs}

Protozoa are simple eukaryotic cells (organisms whose cells have a nuclear membrane) with characteristics of the animal kingdom, since they are mobile and heterotroph; many of these species are cosmopolitan, while others are of limited distribution. ${ }^{56}$

Parasitic infections in humans are increasing due to the emergence of strains that are resistant to antiparasitic compounds, and thus the search and development of new compounds has been undertaken, focusing on extraction and purification of active ingredients of natural or synthetic origin. AMPs could be used in the control of these infections. ${ }^{57}$

The skin of amphibians has been studied, where around 400 peptides with therapeutic potential have been described; most are synthesized in the granular glands that are located on the skin, and play an important role in these species innate immunity. These peptides are involved in the defense of bare skin against pathogenic bacteria and fungi, and also participate in wound repair. ${ }^{58,59}$ They are grouped in 3 families:

- Linear amphipathic helical peptides (magainins and dermaseptins). ${ }^{60}$

- Peptides that contain two cysteine residues on the terminal carboxyl group (brevinins, gaegurins, esculentins, ranatuerins and ranalexin). ${ }^{61-63}$

- Temporins. ${ }^{64,65}$

Dermaseptins are part of an 8-peptide family related to the skin of a South American frog (Phyllomedusa sauvagei). These are linear peptides, of 28 to 34 amino acids, with an $\alpha$-helix structure and are amphipathic in apolar solvents. ${ }^{66}$ They are highly efficacious against protozoa such as Leishmania Mexicana and Plasmodium falciparum. ${ }^{67,68}$

Magainins are molecules isolated from secretions of the skin of the frog Xenopus laevis, ${ }^{69}$ different studies have reported that they have a spectrum with rather broad antimicrobial activity against bacteria, fungi and parasites, in addition to participating in the activation of mechanisms that reduce inflammation. ${ }^{70}$ 
Table 4. Peptides deriving from Hadruroides mauryi and Centruroides margaritatus

\begin{tabular}{|c|c|c|}
\hline Organism & Active fractions & Inhibited microorganisms \\
\hline \multirow[t]{2}{*}{$\begin{array}{l}\text { Hadruroides } \\
\text { mauryi }{ }^{72}\end{array}$} & IV & $\begin{array}{l}\text { Escherichia coli } \\
\text { Pseudomonas aeruginosa } \\
\text { Bacillus cereus }\end{array}$ \\
\hline & VI & Bacillus cereus \\
\hline \multirow{3}{*}{$\begin{array}{l}\text { Centruroides } \\
\text { margaritatus }^{72}\end{array}$} & ॥ & Staphylococcus aureus \\
\hline & III, IV, V and VI & $\begin{array}{l}\text { Staphylococcus aureus } \\
\text { Pseudomonas aeruginosa } \\
\text { Bacillus cereus }\end{array}$ \\
\hline & VII & Pseudomonas aeruginosa \\
\hline
\end{tabular}

\section{Other AMPs. Scorpion venom antibacterial properties}

Although the existence of some antibacterial peptides in scorpion venoms suggests that the venom gland could be protected by these effector molecules, the antibacterial activity of the venom itself has not been extensively assessed. ${ }^{71}$

Some antibacterial peptides of the Hadruroides mauryi and Centruroides margaritatus scorpions' venom have been isolated by ion exchange chromatography (Table 4); although they can be used in the control of bacteria, their activity has to be specifically assessed.72

\section{Conclusion}

Due to the drug resistance presented by microorganisms, implementing new treatment mechanisms is necessary using as models substances of nature that are able to directly act in the control of pathogens or that indirectly activate the host immune system. AMPs can be an excellent option for the treatment of infectious diseases, since there is a large diversity of these molecules, and their uses are not limited to infections caused by common microorganisms (bacteria, viruses, fungi and parasites). Attention has also been paid to those that may be an option against cancer.

Antimicrobial peptides for therapeutic use can be obtained by chemical synthesis or can be directly isolated from some natural source, and hence their number can be rather wide. AMPs by themselves show a broad spectrum, although the possibility of combining them in the treatment of infections, with drugs that are commercially available and conventionally used remains to be explored, in order to assess whether combined therapy can enhance their effect.
The use of these molecules is increasingly common and successful, and even though certain peptides are still at early clinical stages, their use in the medium-term can be a promising option, especially if we consider the drug resistance that many pathogens that generate diseases in humans have developed.

\section{Acknowledgements}

The authors thank Universidad Autónoma Metropolitana Unidad Xochimilco for the support received. The presented work is part of the CB-2015-1-258735 project.

\section{References}

1. Jenssen $H$, Hamill $P$, Hancock RE. Peptide antimicrobial agents. Clin Microbiol Rev. 2006;19:491-511.

2. Hirsch JG. Phagocytin: a bactericidal substance from polymorphonuclear leucocytes. J Exp Med. 1956;103:589-611.

3. Conlon J, Sonnevend A. Antimicrobial peptides in frog skin secretions. Methods Mol Biol. 2010;618:3-14.

4. Radek K, Gallo, R. Antimicrobial peptides: natural effectors of the innate immune system. Semin Immunopathol. 2007;29:27-43.

5. Tonarelli G, Simonetta A. Péptidos antimicrobianos de organismos procariotas y eucariotas como agentes terapéuticos y conservantes de alimentos. FABICI. 2013;17:137-177.

6. Rocha-Ferreira E, Hristova M. Antimicrobial peptides and complement in neonatal hypoxia-ischemia induced brain damage. Front Immunol. 2015;12:6:56.

7. Braff MH, Bardan A, Nizet V, Gallo RL. Cutaneous defense mechanisms by antimicrobial peptides. J Invest Dermatol. 2005;125:9-13.

8. Oppenheim J, Biragyn A, Kwak L, Yang D. Roles of antimicrobial peptides such as defensins in innate and adaptive immunity. Ann Rheum Dis. 2003;62:ii17-ii21.

9. Mastroianni JR, Lu W, Selsted ME, Ouellette AJ. Differential susceptibility of bacteria to mouse Paneth cell $\alpha$-defensins under anaerobic conditions. Antibiotics (Basel). 2014;3:493-508.

10. Guilhelmelli F, Viela N, Albuquerque P, Derengowski L, Silva-Pereira I, Kyaw CM. Antibiotic development challenges: the various mechanisms of action of antimicrobial peptides and of bacterial resistance. Front Microbiol. 2013;4:353.

11. Epand RM, Vogel HJ. Diversity of antimicrobial peptides and their mechanisms of action. Biochim Biophys Acta. 1999;1462:11-28.

12. Yeaman MR, Yount NY. Mechanisms of antimicrobial peptide action and resistance. Pharmacol Rev. 2003;55:27-55.

13. Gordon YJ, Romanowski EG. A review of antimicrobial peptides and their therapeutic potential as anti-Infective drugs. Curr Eye Res. 2005;30:505-515.

14. De Lucca AJ, Walsh TJ. Antifungal peptides: novel therapeutic compounds against emerging pathogens. Antimicrob Agents Chemother. 1999;43:1-11.

15. Buckheit RW, Watson KM, Morrow KM, Ham AS. Development of topical microbicides to prevent the sexual transmission of HIV. Antiviral Res. 2010;85:142-158.

16. Rivas L, Luque-Ortega JR, Andreu D. Amphibian antimicrobial peptides and protozoa: lessons from parasites. Biochim Biophys Acta. 2009:1788:1570-1581.

17. Volzing K, Borrero J, Sadowsky MJ, Kaznessis YN. Antimicrobial peptides targeting Gram-negative pathogens, produced and delivered by lactic acid bacteria. ACS Synth Biol. 2013;2:643-650.

18. Hoskin DW, Ramamoorthy A. Studies on anticancer activities of antimicrobial peptides. Biochim Biophys Acta. 2008;1778:357-375.

19. Kim DH, Lee IH, Nam ST, Hong J, Zhang P, Hwang JS, et al. Neurotropic and neuroprotective activities of the earthworm peptide lumbricusin. Biochem Biophys Res Commun. 2014;448:292-297.

20. Enoch D, Ludlam HA, Brown NM. Invasive fungal infections: a review of epidemiology and management options. J Med Microbiol. 2006:55:809-818.

21. De Luca AJ, Walsh TJ. Antifungal peptides: origin, activity, and therapeutic potential. Rev Iberoam Micol. 2000;17:116-120.

22. Shai $Y$. Molecular recognition between membrane-spanning polypeptides. Trends Biochem Sci. 1995;20:460-464.

23. Rautenbach M, Troskie AM, Vosloo JA. Antifungal peptides: To be or not to be membrane active. Biochimie. 2016;130:132-145. 
24. De Lucca AJ, Walsh TJ. Antifungal peptides: novel therapeutic compounds against emerging pathogens. Antimicrob Agents Chemother. 1999;43:1-11.

25. Swidergall M, Ernst JF. Interplay between Candida albicans and the antimicrobial peptide armory. Eukaryot Cell. 2014;13:950-957.

26. Taylor K, Barran PE, Dorin JR. Structure-activity relationships in beta-defensin peptides. Biopolymers. 2008;90:1-7.

27. Duncan VMS, O'Neil DA. Commercialization of antifungal peptides. Fungal Biol Rev. 2013;26:156-165.

28. Kang HK, Kim C, Seo $\mathrm{CH}$, Park $\mathrm{Y}$. The therapeutic applications of antimicrobial peptides (AMPs): a patent review. J Microbiol. 2017;55:1-12.

29. López-Abarrategui C, Alba A, Silva ON, Reyes-Acosta O, Vasconcelos IM Oliveira JT, et al. Functional characterization of a synthetic hydrophilic antifungal peptide derived from the marine snail Cenchritis muricatus. Biochimie. 2012;94:968-974.

30. Lee JU, Kang DI, Zhu WL, Shin SY, Hahm KS, Kim Y. Solution structures and biological functions of the antimicrobial peptide, arenicin-1, and its linear derivative. Biopolymers. 2007;88:208-216.

31. Rossignol T, Kelly B, Dobson C, D'Enfert C. Endocytosis-mediated vacuolar accumulation of the human ApoE apolipoprotein-derived ApoEd$\mathrm{pL}-\mathrm{W}$ antimicrobial peptide contributes to its antifungal activity in Candida albicans. Antimicrob Agents Chemother. 2011;55:4670-4681.

32. Kabir ME, Krishnaswamy S, Miyamoto M, Furuichi Y, Komiyama T. An altered camelid-like single domain anti-idiotypic antibody fragment of HM-1 killer toxin: acts as an effective antifungal agent. Appl Microbio Biotechnol. 2011;90:553-564.

33. López-García B, Pérez-Payá E, Marcos JF. Identification of novel hexapeptides bioactive against phytopathogenic fungi through screening of a synthetic peptide combinatorial library. Appl Environ Microbiol. 2002; 68:2453-2460.

34. De Lucca AJ. Antifungal peptides: potential candidates for the treatment of fungal infections. Expert Opin Investig Drugs. 2000;9:273-299.

35. Hawser S, Borgonovi M, Markus A, Isert D. Mulundocandin, an echinocandin-like lipopeptide antifungal agent: biological activities in vitro. J Antibiot (Tokyo). 1999;52:305-310.

36. Qureshi A, Thakur N, Tandon H, Kumar M. AVPdb: a database of experimentally validated antiviral peptides targeting medically important viruses. Nucleic Acids Res. 2014;42:D1147-D1153.

37. Imanishi J, Oku T, Cho Y, Inagawa S, Tanaka A, Kuwayama W. Inhibition of virus multiplication by immunoactive peptides. C R Seances Soc Biol Fil. 1985;179:414-419.

38. Zasloff, M. Antimicrobial peptides of multicellular organisms. Nature. 2002;415:389-395.

39. Fung HB, Guo Y. Enfuvirtide: a fusion inhibitor for the treatment of HIV infection. Clin Ther. 2004;26:352-378.

40. Wachinger M, Kleinschmidt A, Winder D, Von-Pechmann N, Ludvigsen A Neumann $M$, et al. Antimicrobial peptides melittin and cecropin inhibit replication of human immunodeficiency virus 1 by suppressing viral gene expression. J Gen Virol. 1998;79:731-740.

41. Albiol-Matanic VC, Castilla V, et al. Antiviral activity of antimicrobial cationic peptides against Junin virus and herpes simplex virus. Int $J$ Antimicrob Agents. 2004;23:382-389.

42. Chernysh S, Kim SI, Bekker G, Pleskach VA, Filatova NA, Anikin VB et al. Antiviral and antitumor peptides from insects. Proc Natl Acad Sci U S A. 2002:99:12628-12632.

43. Slocinska M, Marciniak P, Rosinski G. Insects antiviral and anticancer peptides: new leads for the future? Protein Pept Lett. 2008:15:578-585.

44. Ourth DD. Antiviral activity against human immunodeficiency virus-1 in vitro by myristoylated-peptide from Heliothis virescens. Biochem Biophys Res Commun. 2004;320:190-196.

45. Elliott G, O'Hare P. Intercellular trafficking and protein delivery by a herpesvirus structural protein. Cell. 1997;88:223-233.

46. Delcroix M, Riley LW. Cell-penetrating peptides for antiviral drug development. Pharmaceuticals (Basel). 2010;3:448-470.

47. Arpornsuwan T, Buasakul B, Jaresitthikunchai J, Roytrakul S. Potent and rapid antigonococcal activity of the venom peptide $\mathrm{BmKn} 2$ and its derivatives against different Maldi biotype of multidrug-resistant Neisseria gonorrhoeae. Peptides. 2014;53:315-320.

48. Hirt H, Gorr SU. Antimicrobial peptide GL13K is effective in reducing biofilms of Pseudomonas aeruginosa. Antimicrob Agents Chemother. 2013:57:4903-4910.
49. Volzing K, Borrero J, Sadowsky MJ, Kaznessis YN. Antimicrobial peptides targeting Gram-negative pathogens, produced and delivered by lactic acid bacteria. ACS Synth Biol. 2013;2:643-650.

50. Brogden NK, Brogden KA. Will new generations of modified antimicrobial peptides improve their potential as pharmaceuticals? Int J Antimicrob Agents. 2011;38:217-225.

51. Rivas-Santiago B, Sada E, Hernández-Pando R, Tsutsumi V. Péptidos antimicrobianos en inmunidad innata de enfermedades infecciosas. Salud Publica de Mex. 2006;48:62-71.

52. Dong H, Lv Y, Zhao D, Barrow P, Zhou X. Defensins: the case for their use against mycobacterial infections. J Immunol Res. 2016;2016: 7515687

53. Palumbo D, lannaccone M, Porta A, Capparelli R. Experimental antibacterial therapy with puroindolines, lactoferrin and lysozyme in Listeria monocytogenes-infected mice. Microbes Infect. 2010;12:538-545.

54. Rodríguez-Franco DA, Vázquez-Moreno L, Ramos-Clamont Montfort G. Actividad antimicrobiana de la lactoferrina: mecanismos y aplicaciones clínicas potenciales. Rev Latinoam Microbiol. 2005;47:102-111.

55. Liou JW, Hung YJ, Yang $\mathrm{CH}$, Chen YC. The antimicrobial activity of gramicidin $\mathrm{A}$ is associated with hydroxyl radical formation. PLoS One. 2015;10:e0117065.

56. Yaeger RG. Protozoa: Structure, classification, growth, and development. En: Baron S, editor. Medical Microbiology. Cuarta edición. EE.UU.: University of Texas Medical Branch at Galveston; 1996.

57. Téllez GA, Castaño JC. Péptidos antimicrobianos. Infection. 2010;14:55-67.

58. Hancock RE. Cationic peptides: effectors in innate immunity and novel antimicrobials. Lancet Infect Dis. 2001;1(3):156-164.

59. Wang Z, Wang G. APD: the antimicrobial peptide database. Nucleic Acids Res. 2004;1:590-592.

60. Rollins-Smith LA, Conlon JM. Antimicrobial peptide defenses against chytridiomycosis, an emerging infectious disease of amphibian populations. Dev Comp Immunol. 2005;29:589-598

61. Cirioni O, Giacometti A, Ghiselli R, Mocchegiani F, Fineo A, Orlando F, et al. Single-dose intraperitoneal magainins improve survival in a gram-negative-pathogen septic shock rat model. Antimicrob Agents Chemother. 2002;46:101-104.

62. Clark DP Durell S, Maloy WL, Zasloff M. Ranalexin. A novel antimicrobial peptide from bullfrog (Rana catesbeiana) skin, structurally related to the bacterial antibiotic, polymyxin. J Biol Chem. 1994;269:10849-10855.

63. Goraya J, Wang Y, Li Z, O'Flaherty M, Knoop FC, Platz JE, et al. Peptides with antimicrobial activity from four different families isolated from the skins of the North American frogs Rana luteiventris, Rana berlandieri and Rana pipiens. Eur J Biochem. 2000;267:894-900.

64. Conlon JM, Kolodziejek J, Nowotny N. Antimicrobial peptides from ranid frogs: taxonomic and phylogenetic markers and a potential source of new therapeutic agents. Biochim Biophys Acta. 2004;1696:1-14.

65. Simmaco M, Mignogna G, Canofeni S, Miele R, Mangoni ML, Barra D. Temporins, antimicrobial peptides from the European red frog Rana temporaria. Eur J Biochem. 1996;242:788-792.

66. Mor A, Nicolas P. Isolation and structure of novel defensive peptides from frog skin. Eur J Biochem. 1994;219:145-154

67. Mor A, Hani K, Nicolas $P$. The vertebrate peptide antibiotics dermaseptins have overlapping structural features but targets specific microorganisms. Biol Chem. 1994;269:31635-31641

68. Krugliak M, Feder R, Zolotarev VY, Gaidukov L, Dagan A, Ginsburg H, et al. Antimalarial activities of dermaseptin S4 derivatives. Antimicrob Agents Chemother. 2000;44:2442-2451.

69. Zasloff M. Magainins, a class of antimicrobial peptides from Xenopus skin: isolation, characterization of two active forms, and partial cDNA sequence of a precursor. Proc Natl Acad Sci U S A. 1987;84:5449-5453.

70. Wakamatsu K, Takeda A, Tachi T, Matsuzaki K. Dimer structure of magainin 2 bound to phospholipid vesicles. Biopolymers. 2002;64:314-327.

71. Verdonck F, Bosteels S, Desmet J, Moerman L, Noppe W, Willems J, et al. A novel class of pore-forming peptides in the venom of Parabuthus schlechteri Purcell (scorpions: buthidae). Cimbebasia. 2000;16:247-260.

72. Escobar E, Flores L, Rivera C. Péptidos antibacterianos de los venenos de Hadruroides mauryi y Centruroides margaritatus. Rev Peru Biol. 2008;15:139-142. 